\title{
The Impact of Students' Understanding of Anti-Corruption Values on Anti-Corruption Behavior
}

\author{
${ }^{1}$ NURHAYANI SARAGIH, ${ }^{2}$ SURAYA MANSUR, ${ }^{3 T R I ~ W A H Y U T I, ~}{ }^{4}$ RINI SUDARMANTI \\ ${ }^{1}$ Universitas Mercu Buana, Jalan Meruya Selatan No. 1, Jakarta Barat, DKI Jakarta, ${ }^{2}$ Universitas Mercu Buana, \\ Jalan Meruya Selatan No. 1, Jakarta Barat, DKI Jakarta, 3Universitas Paramadina, Jalan Gatot Subroto Kav. 97 \\ Jakarta, DKI Jakarta, ${ }^{4}$ Universitas Paramadina, Jalan Gatot Subroto Kav. 97 Jakarta, DKI Jakarta \\ email: 1nurhayani.saragih@mercubuana.ac.id; ${ }^{2}$ suraya.suraya@mercubuana.ac.id; \\ 3tri.wahyuti@paramadina.ac.id; ${ }^{4}$ rini.sudarmanti@paramadina.ac.id
}

\begin{abstract}
This study aims to examine the impact of students' understanding of anticorruption values on anti-corruption behavior. A quantitative exploratory survey with the positivist paradigm is employed in this study. Data are collected by distributing a questionnaire to 100 Public Relations students as the sample chosen by the purposive sample technique. Then, data are analyzed using simple linear regression. The results show that all respondents are in the category of having high anti-corruption values behavior. However, the correlation between their understanding and anti-corruption values is moderate, while the correlation between their understanding and corruptive behavior is low. Based on the data above, this study concludes that the impact of understanding the anti-corruption values on anti-corruption and corruptive behavior is not significant and categorized as weak. Therefore, anti-corruption values should be strengthened not only through the courses at university but also in the family.
\end{abstract}

Keywords: Corruption, Corruptive, Integrity

\section{Introduction}

Corruption is one of the serious issues in Indonesia. Indonesia's Corruption Perception Index (CPI) 2020 is on the $102^{\text {nd }}$ rank of 180 surveyed countries with a score of 37 . Previously in 2019, Indonesia's CPI was on the $85^{\text {th }}$ rank with the score of 40 . Indonesia's ranking is the same as Gambia (a country in West Africa). However, Indonesia's ranking is still better than other Asean countries such as Vietnam, Thailand, Philippines, Laos and Cambodia. However, it is still far behind from Singapore, Brunei Darussalam, Malaysia and Timor Leste (Madrim, 2021).

The CPI data shows that corruption in Indonesia has become a culture as the index was obtained from the review of nine other indexes, such as the EOS of The World Economy Forum, the PRS International Country Risk Guide, and the World Justice Project - Rule of Law Index. The government has made various efforts to eradicate corruption, including by establishing the Corruption Eradication Commission (KPK) in 2002. The government has also begun to implement digitization of services such as e-ticketing, e-smart, e-samsat, e-procurement, e-budgeting, and e-planing. The digitization of services is claimed to be effective in eradicating corruption. However, the Corruption Perception Index above shows that the effort has made only a few changes.

Corruption is a social plague: gains accrue to small groups, while its costs are borne by everyone (Wachs et al., 2019). Corruption is a form of moral decay, depravity, dishonesty, bribery, immoral, and also a deviation from holiness. Malaysia employs the word "resuah" from the Arabic "risywah", which means corruption. Risywah (bribery) terminologically means giving something to a judge or another powerful person to win a certain case in an unjustified manner or to obtain a position (Harahap, 2018). All

Received: June 21, 2020, Revision: October 13, 2020, Accepted: June 08, 2021

Print ISSN: 0215-8175; Online ISSN: 2303-2499. DOI: https://doi.org/10.29313/mimbar.v37i1.6310

Accredited Sinta 2 based on the decree No.10/E/KPT/2019 until 2024. Indexed by DOAJ, Sinta, Garuda, Crossreff, Dimensions 
the religious leaders agree to forbid risywah which is also associated with breaking the law and included as a sin. Corruption is immoral action committed by anyone at any time, and anywhere. The corruptors abuse their authority and power for the interests of their own selves, relatives, or certain group. (Handoyo, 2013).

The failure in moral education for the young generation is caused by the national education system that lacks a strong character education curriculum model that is integrated into every course. Although understanding character and morality, such as religion, manner, nationalism, and Pancasila have been implemented on a certain course, the learning activity is still limited to cognitive guidance and the psychomotor aspect should be considered more (Dimyati, 2018).

In order to raise the awareness of AntiCorruption, the Directorate General of Higher Education includes Anti-Corruption courses in the higher education curriculum. DIKTI since 2012, together with Bandung Institute of Technology, Paramadina University, University of Indonesia, Padjadjaran University, Semarang State University, UNIKA Soegijapranata, Corruption Eradication Commission (KPK), Making Integrity Work (TIRI), and Indonesia Corruption Watch (ICW), created an Anti-Corruption course curriculum. As a guide, the Ministry of Research, Technology and Higher Education has published an Anti-Corruption Education Learning Guide for Higher Education (Puspito \& Elwina, 2016).

Higher education institutions hold a central role in preventing corruption, essentially in developing anti-corruption culture, law awareness, and integrity values to the students (Saifulloh, 2017); (Suryani, 2015). Anti-corruption education is aimed to educate the students about the corruption issue and the prevention efforts. Mercu Buana University that has been established since 1985 has been integrating anticorruption values and integrity in all learning aspects.

Anti-corruption values and integrity establishment are essential parts in building students' character. Students are expected to not only capable in the academic level but also to have integrity showed through anti-corruption values implemented in daily activity. Based on the background, the research question would be: "How does the understanding of anti-corruption value affect the anti-corruption and corruptive behavior of Mercu Buana University students?"

Similar studies have been conducted, among others, by Benni Kurnia Illahi (Illahi, 2019) discussing The Internalization Of AntiCorruption Values; The Implementation of Anti-Corruption Values by (Suryani, 2015); The role of Higher Education Institution in Anti-Corruption Education by (Saifulloh, 2017); Anti-Corruption Doctrine In Higher Education Institution by (Habibi, 2018); Challenges in Anti-Corruption by (Wiyono, 2015); Academic Jihad Against Corruption by (Khamdan, 2014); and Anti-corruption in Islam Education by (Hermawan, 2018).

The communication process is ubiquitous; this activity can be conducted anywhere including in the context of education. Communication becomes an essential part of the learning process and material delivery in order to gain maximum and expected output. Some researchers explained about it in their research, among others are Studies on communication education (Nurul Salmi Mohd Dazali \& Mohd Isha Awang, 2014); Communication between teachers and students (Mohd Khairuddin Abdullah et al., 2014); Effective Communication in Education (Wisman, 2017).

Learning material is a form of the message conveyed to students (communicants). The message received results in a change, which is known as the communication effect. Effendy explained that based on its level, the communication effect is classified into cognitive effect, affective effect, and behavioral effect (Effendy, 2003); (Oktarina \& Abdullah, 2017). Cognitive effects can increase the knowledge of communicants. Affective effect aimed to not only add knowledge but also affect the communicant's emotion that can lead to behavioral effect, where there is a change in the communicant's behavior after the communication process.

The effect can occur because of the communication process during the learning process. Although there has not been a specific course on anti-corruption, Mercu Buana University students are equipped with religious subjects, Mercu Buana Ethics, and various other courses that teach the students to always uphold integrity in their behavior. In order to measure the effects of communication, this study employed levels 
of understanding (cognitive effects) and behavior (behavior effects) in accordance with anti-corruption values and behavioral effects on corrupt behavior as the variables.

Understanding is perceived as a person with certain knowledge or someone who properly understands about a certain thing. Understanding in education research (Lestari \& Romdiani, 2018); (Soemanto et al., 2014)including public officials (Djulianto, 2009 is something understood, in this study is the anti-corruption value. Knowledge is the cognitive effect on the communication act (Pramelani, 2018)the government a s of October 31, 2017 issued a requirement that all prepaid cellular cards be re-registered by sending NIK (Resident Identity Number. Someone understands when he or she is able to mention the points of the materials received, in this study, it is the points of anti-corruption values. Value is the content meaning and message or implied and explicit meaning within a fact, concept, and also theory. Values become the standard of human behavior and function as director, controller, and the determinant of someone's trait. The value represents an individual's understanding and also behavior or reaction towards something (Salama, 2014).

The effort to prevent corruption can be started by implementing anti-corruption values and principles to the students. There are nine anti-corruption values that can be implemented: honesty, caring, independence, discipline, responsibility, hard work, modesty, courage, and justice (Puspito \& Elwina, 2016); (Nugraheni; Lestari, 2018), and (Handoyo, 2013).

Honesty is shown by the act of not cheating during exams. Honest means not cheating, not taking credit of the work or duties of others as our own. The value of care can be seen when students pay attention and maintain an inventory of the campus, and report to the appropriate authorities if necessary. Independence can be seen from the effort to do the assignments and tests without help from others. Discipline is shown when the students obey the rules, be on time, including submit assignments on time.

Responsibility is shown by the readiness to bear the consequences of acts of communication, both intentional and unintentional. Hardworking means having the determination and perseverance to finish college on time with all abilities. Modesty is to live their life in accordance with their ability and financial condition, not spending other people's belongings or money, except in urgent conditions. Courage is seen in the form of being able to speak the truth, dare to admit mistakes, and be responsible for all behaviors. Justice is shown when students can solve a problem between two parties fairly in daily activity.

The level of understanding can be perceived through the ability of students to interpret anti-corruption values. Behavior is all human activities or activities, which can be seen directly or indirectly by others. Change in behavior is one of the effects of communication. In this study, the behavior is interpreted as a communication act by the students that consider anti-corruption values such as honesty, caring, independence, discipline, responsibility, hard work, modesty, courage, and justice.

The form of corruption in "Pendidikan Anti-Korupsi untuk Perguruan Tinggi" ("AntiCorruption Study for Higher Education") are conflict of interest, gratification, racketeering, financial losses, fraudulent actions, and bribery. Corruptive behavior in this study is described based on the forms of corruption described, including embezzlement and nepotism (Handayani, 2019).

The most widely used and accepted definition of bribery is the "misuse of public office for private gain (Williams et al., 2016). Bribery is not always in the form of money, but can be in the form of goods, references, privileges, benefits or promises that can be used to persuade or influence someone's actions, votes, or influence in a public office. Bribery in campus can happen when the students give a certain amount of money, goods, and anything to the staff or lecturers who have the authority over an academic policy to get a certain privilege.

Embezzlement is defined as the misappropriation of assets by individuals to whom they were entrusted, in order to monopolize or to steal them (Attanasi et al., 2019). Mark-up refers to the misuse of the information in order to persuade a certain party to give their asset or money voluntarily. Embezzlement is purposed for personal interest such as using the campus facility irresponsibly or deliberately lost it. Mark-up could be in the form of editing the budget more than what is actually needed, for instance, manipulating their parents about tuition fees or manipulating the budget for organization activity. 
Blackmailing is a threat of violence or an act of spreading information to threaten someone's reputation in order to force him or her to cooperate. For example, bad students can blackmail other students or a certain organization by forcing them to prepare the tasks or cheat. Nepotism or also called kinship corruption involves the appointment of relatives, friends or political colleagues in public positions regardless of their ability to provide good public services and support the welfare of the community (Iqbal \& Ahmad, 2020). Nepotism can occur in the campus environment, for instance, voting for class leaders based on personal closeness, choosing students' activity unit and its members based only on closeness as friends, and does not give other students the opportunity to become members of the organization.

The understanding of anti-corruption values can create anti-corruption behavior among students and lessen corruptive behavior. The lack of academic integrity greatly impacts academic processes in the higher education sector around the world. Bribery, plagiarism, and other forms of deception that enable students to obtain undeserved grades or degree certificates undermine the purpose and mission of higher education (Denisova-Schmidt et al., 2019).

\section{Research Methodology}

An exploratory survey with a quantitative approach was employed in this study (Sugiyono, 2016). Explanatory research aimed to explain a sample generalization to its population or to explain the relationship, difference, and impact of a certain variable to another (Sugiyono, 2016). This study examined the impact of the understanding of anti-corruption values as an independent variable $(X)$ on anti-corruption behavior $(\mathrm{Y} 1)$, and corruptive behavior (Y2) of Mercu Buana University students as the dependent variables.

The survey method was employed to gain the data related to belief, opinion, characteristics, behavior, the relationship of variables, and also to test several hypotheses on sociological variables from the samples taken in a certain population. The data were collected through interviews or questionnaires and the results tended to be generalized. (Lina Miftahul Jannah \& Bambang Prasetyo, 2003). The study was conducted for six months, starting June 2019 until January 2020. The study included proposal and questionnaire arrangement, questionnaire distribution, data processing, and report arrangement.

Purposive sampling was employed in collecting the sample. Purposive sampling is a technique to gain samples through a certain consideration (Sugiyono, 2016). The considerations are students who have passed religion, Mercu Buana ethics, and research method courses. Population of this study is the students of Public Relations study program.

Validity test was conducted by calculating Corrected Item-Total Correlation value ( $R$-count) for each statement, compared to the $r$-value of the table (on significance value of 0.05 ) and to the number of the data of $(n)=100$, then it is known that $r$ table is 0.195 . The calculation result showed that the entire statements of variable $X$ and $Y$ have $r$-count value $>r$ table. It can be concluded that all statements in variables $\mathrm{X}, \mathrm{Y} 1$, and $\mathrm{Y} 2$ are valid. The Cronbach's Alpha value of the variables is presented in table 1 .

Table 1

Reliability Result

\begin{tabular}{ccl}
\hline Variable & $\begin{array}{c}\text { Cronbach's Alpha } \\
\text { Value }\end{array}$ & Information \\
\hline $\mathrm{X}$ & 0.930 & Reliable \\
Y1 & 0.885 & Reliable \\
Y2 & 0.850 & Reliable \\
\hline
\end{tabular}

Table 1 above showed that Cronbach's alpha value of the variables is greater than 0.6 . The principle to conclude the result of the reliability test is: if the Cronbach's Alpha value $>0.6$, then the questionnaire is reliable or consistent (Yusup, 2018).

\section{Results and Discussion}

Most of the respondents are female ( $80 \%)$ since the majority of the students are indeed female. However, the age varies as $15 \%$ of the total respondents are under 20 years old, $10 \%$ are $24-25$ years old, and 75\% are 21-24 years old.

Respondents' understanding of anticorruption values is at an excellent level $(87 \%)$. The mean value of the respondents' answers to anti-corruption behavior is above 3. Furthermore, on the statements regarding 
independence, discipline, hard work, and courage, from every two statements submitted, one of the mean values is categorized as good. However, the entire answers of the respondents are categorized as excellent.

On variable Y2 which discusses corruptive behavior, the mean value is categorized as excellent, in which there are only two statements with "good" mean value (regarding bribery and nepotism). Most of the respondents (91\%) never committed corruptive action and behavior at a higher level, and $9 \%$ of the respondents are in the medium category.

The results of the normality error regression test were gained by using the
Kolmogorov-Smirnov model of the residual variables. Residual normality test results showed that in variable $X$ the level of understanding of anti-corruption values was (0.058), Variable Y1 Anti-Corruption Behavior was (0.062) and Variable Y2 was (0.071) asymp.sig value > alpha 0.05 . Thus, Ho was failed to be rejected which means the distribution of residual values in the regression equation model on variables $\mathrm{X}, \mathrm{Y} 1$ and $\mathrm{Y} 2$ were expressed in a normal distribution.

Pearson product-moment results showed Variable $X$ (Level of understanding of anti-corruption values) to variable $Y 1$ (anti-corruption behavior), and Variable $X$ to variable $\mathrm{Y} 2$ (corruptive behavior), as follows:

Table 2.

Correlations Test

\begin{tabular}{ccccc}
\hline & & $\mathrm{X}$ & $\mathrm{Y} 1$ & $\mathrm{Y} 2$ \\
\hline \multirow{3}{*}{ Interval $\mathrm{X}$} & Pearson Correlation & 1 & $.504^{* *}$ & $.338^{* *}$ \\
& Sig. (2-tailed) & & .000 & .001 \\
$\mathrm{~N}$ & 100 & 100 & 100 \\
\hline$* *$ The correlation is significant at the & 0.01 level (2-tailed)
\end{tabular}

The correlation value ( $r$ ) obtained showed the relationship between variable $X$ (Understanding Level of Anti-Corruption Values) and Variable Y1 (Anti-Corruption Behavior) of $0.504 /$ moderate. Correlation results $(r)$ in the table showed the relationship between variable $X$ (Level of Understanding of Anti-Corruption Values) and Variable Y2 (Corruptive behavior) of $0.338 /$ low.

Table 3.

Regression Test/Variable $X$ to $Y 1$ Model Summary

\begin{tabular}{|c|c|c|c|c|c|c|c|c|c|}
\hline \multirow[b]{2}{*}{ Model } & \multirow[b]{2}{*}{$\mathrm{R}$} & \multirow[b]{2}{*}{ R Square } & \multirow[b]{2}{*}{$\begin{array}{l}\text { Adjusted } \\
\text { R Square }\end{array}$} & \multirow[b]{2}{*}{$\begin{array}{c}\text { Std. Error of the } \\
\text { Estimate }\end{array}$} & \multicolumn{5}{|c|}{ Change Statistics } \\
\hline & & & & & $\begin{array}{c}\text { R } \\
\text { Square } \\
\text { Change }\end{array}$ & $\begin{array}{c}\mathrm{F} \\
\text { Change }\end{array}$ & $\mathrm{df1}$ & $\mathrm{df2}$ & $\begin{array}{l}\text { Sig. F } \\
\text { Change }\end{array}$ \\
\hline 1 & $.504^{a}$ & .254 & .247 & .293 & .254 & 33.442 & 1 & 98 & .000 \\
\hline
\end{tabular}

a. Predictors: (Constant), Interval Y1

b. Dependent Variable: Interval $X$

The impact of variable $X$ (Level of Understanding of Anti-Corruption Values) on $\mathrm{Y} 1$ (Corruptive Behavior) is $25.4 \%$, while the rest is $74.6 \%$, which is affected by other factors outside the focus of this study.

Table 4

Coefficients ${ }^{a}$

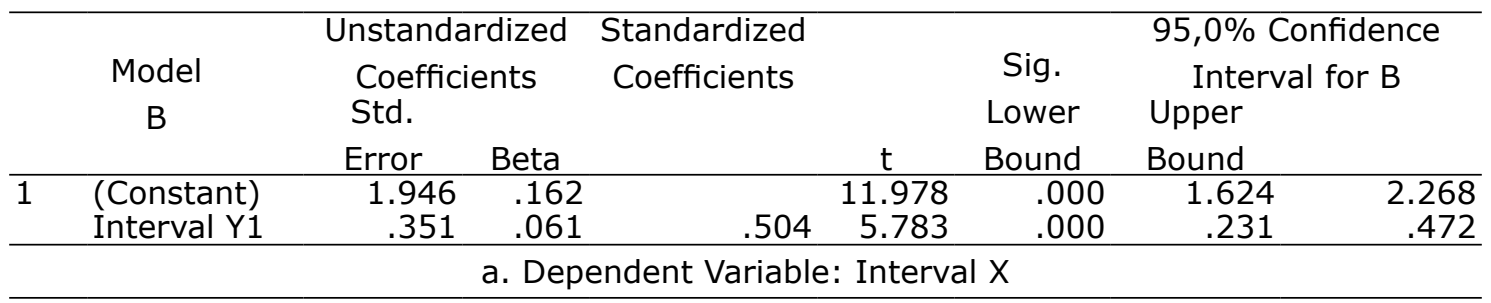


Through the coefficient table above, it is obtained that constant value (a) is 1.946 and regression coefficient is 0.351 . Based on the constant value and regression coefficient, the regression equation below could be obtained:

$$
\begin{aligned}
& Y=a+b X \\
& Y 1=1,946+0,351 X
\end{aligned}
$$

The regression coefficient value of Variable $\mathrm{X} 1$ is 0.351 , which means every one (1) score increases of Variable $X$ (Level of Understanding of Anti-Corruption Value) would increase the score of Variable Y1 (Anti-Corruption Behavior) to 1.946. The regression coefficient is positive, which means the direction of the impact of variable $X$ on $Y 1$ (Anti-Corruption Behavior) is positive.

\section{Table 5.}

\section{Variabel $X$ to Y2 Regression Test}

\begin{tabular}{|c|c|c|c|c|c|c|c|c|c|}
\hline \multirow[b]{2}{*}{ Model } & \multirow[b]{2}{*}{$\mathrm{R}$} & \multirow[b]{2}{*}{ R Square } & \multirow[b]{2}{*}{$\begin{array}{c}\text { Adjusted R } \\
\text { Square }\end{array}$} & \multirow{2}{*}{$\begin{array}{l}\text { Std. Error } \\
\text { of the } \\
\text { Estimate }\end{array}$} & \multicolumn{5}{|c|}{ Change Statistics } \\
\hline & & & & & $\begin{array}{c}\text { R Square } \\
\text { Change }\end{array}$ & F Change & df1 & $\mathrm{df} 2$ & $\begin{array}{l}\text { Sig. F } \\
\text { Change }\end{array}$ \\
\hline 1 & $.338^{a}$ & .114 & .105 & .320 & .114 & 12.659 & 1 & 98 & .001 \\
\hline \multicolumn{10}{|c|}{ a. Predictors: (Constant), Interval Y2 } \\
\hline
\end{tabular}

Model Summaryb

Variable X1 (The level of understanding of Anti-Corruption Values) affected Variable Y1 (Anti-Corruption Behavior) for $11.4 \%$ while the rest $(88.6 \%)$ was affected by other unknown variables.

Table 6

\begin{tabular}{|c|c|c|c|c|c|c|c|c|}
\hline \multirow{2}{*}{\multicolumn{2}{|c|}{$\begin{array}{l}\text { Model } \\
\text { B }\end{array}$}} & \multicolumn{2}{|c|}{$\begin{array}{c}\text { Unstandardized } \\
\text { Coefficients }\end{array}$} & \multirow[t]{2}{*}{$\begin{array}{l}\text { Standardized } \\
\text { Coefficients }\end{array}$} & \multirow[t]{2}{*}{$\mathrm{t}$} & \multirow{2}{*}{$\begin{array}{l}\text { Sig. } \\
\text { Lower } \\
\text { Bound }\end{array}$} & \multirow{2}{*}{\multicolumn{2}{|c|}{$\begin{array}{l}95,0 \% \text { Confidence } \\
\text { Interval for B } \\
\text { Upper }\end{array}$}} \\
\hline & & Std. Error & Beta & & & & & \\
\hline 1 & $\begin{array}{l}\text { (Constant) } \\
\text { Interval Y2 }\end{array}$ & $\begin{array}{c}2.290 \\
.223\end{array}$ & $\begin{array}{l}.166 \\
.063\end{array}$ & .338 & $\begin{array}{c}13.785 \\
3.558\end{array}$ & $\begin{array}{l}.000 \\
.001\end{array}$ & $\begin{array}{l}1.960 \\
.099\end{array}$ & $\begin{array}{c}2.620 \\
.347\end{array}$ \\
\hline \multicolumn{9}{|c|}{ a. Dependent Variable: Interval X } \\
\hline
\end{tabular}

Coefficients $^{a}$

Table 6 above shows that the constant value (a) is 2.290 and the regression coefficient is 0.223 . Based on the constant value and regression coefficient, the regression equation can be obtained as shown below:

$$
\begin{aligned}
& Y=a+b X \\
& Y 2=2,290+0,223 X
\end{aligned}
$$

The linear equation above can be interpreted as follows: The constant value is 2.290 , which means the total score level of understanding anti-corruption values is 2.290. The regression coefficient value of Variable X (Level of Understanding of AntiCorruption Values) is 0.223 , which means every one increase of score of Variable X1 will increase the score of variable $Y 2$ of 0.223 . The coefficient regression is positive; thus, the impact of variable $X$ on $Y$ is positive. The result of the ANOVA test is reflected in the table below:

Table 7. ANOVA ${ }^{b}$

\begin{tabular}{ccccccc}
\hline \multirow{2}{*}{ Model } & $\begin{array}{c}\text { Sum of } \\
\text { Squares }\end{array}$ & df & $\begin{array}{c}\text { Mean } \\
\text { Square }\end{array}$ & $F$ & Sig. \\
\hline \multirow{3}{*}{1} & Regression & 2.878 & 1 & 2.878 & 33.442 & $.000^{\text {a }}$ \\
& Residual & 8.432 & 98 & .086 & & \\
& Total & 11.310 & 99 & & \\
\hline \multicolumn{5}{c}{ a. Predictors: (Constant), Interval Y1 } \\
\hline
\end{tabular}


Table 7 above shows simultaneous significance. The results of the ANOVA test can be perceived through $\mathrm{F}$ value $=33.442$, $\mathrm{p}(\mathrm{sig})=0.000$. In order to determine whether the dependent variable is significant or not, the analysis was conducted by using F-test with a liability level of $95 \%$ or a significant standard of $5 \%(0.05)$. Based on the result of F-table calculation, the value of F-table produced is 3.09. Thus, it can be concluded that F-count $>$ F-table with the calculation value $33.442>3.09$. Based on F-test, it is known that (Ho) is rejected and $(\mathrm{Ha})$ is accepted, which means $X$ has given a positive and significant impact on $\mathrm{Y} 1$.

Table 8. ANOVA ${ }^{b}$

\begin{tabular}{ccccccc}
\hline & \multicolumn{5}{c}{ Sum of } & \multicolumn{3}{c}{ Mean } \\
& Model & Squares & $\mathrm{df}$ & Square & $\mathrm{F}$ & Sig. \\
\hline 1 & Regression & 1.294 & 1 & 1.294 & 12.659 & $.001^{\text {a }}$ \\
& Residual & 10.016 & 98 & .102 & & \\
& Total & 11.310 & 99 & & \\
\hline \multicolumn{5}{c}{ a. Predictors: (Constant), Interval Y2 } \\
\hline
\end{tabular}

The table above showed simultaneous significance. The result of ANOVA test can be perceived through $\mathrm{F}$ value $=1.659, \mathrm{p}$ ( $\mathrm{sig}$ ) $=0.001$. In order to determine whether the dependent variable has a significant impact or not, an analysis by employing F-test was conducted with a liability level of $95 \%$, or significant standard of $5 \%(0.05)$. The result of F-table calculation: the value of F-table produced is 3.09 . It can be concluded that F-count $>$ F-table with the calculation value of $12.659>3.09$. Based on F-test, it is known that ( $\mathrm{Ho})$ is rejected and (ha) is accepted, which means $X$ has given a positive and significant impact on Y2.

\section{Discussion}

The correlation generated from the two variables indicates a moderate relationship. The process of anti-corruption values learning on respondents has a significant effect, where the results of the study showed that their understanding of anti-corruption values has influenced their attitudes and behavior on various actions that lead to anticorruption actions. Anti-corruption education is considered capable of forming an anticorruption character, but it will not be able to eradicate corruption if it is not accompanied by preventive efforts in everyday life. Therefore, understanding corruption as negative values that harm many parties is very important (Widhiyaastuti \& Ariawan, 2018). Through education, anti-corruption characters such as honesty, hard working, courage, responsibility, independence, simplicity, justice and tolerance will be created from an early age (Komalasari \&
Saripudin, 2015) and (SOFWAN et al., 2018).

The results of regression calculation are the important point in this study. The constant value obtained is quite large. This is certainly encouraging because it indicates that the respondents have been exposed to various information about corruption in Indonesia. They are not only exposed to information, but also have a fairly good understanding of corruption. The socialization of integrity values has been implemented through their social groups. They also remember various reports of corruption cases. Thus, it can be concluded that the educational process at the university level could strengthen their understanding. This is in line with the results of a study on the socialization of anticorruption culture in children (Purba \& Zaini, 2018).

The results also showed a relatively low level of understanding and the influence of anti-corruption education. This description indicates that respondents are not aware of their role as agents of change in preventing criminal acts of corruption. Even though students as the younger generation have a sufficient understanding of the complexities of various corruption problems in Indonesia and the importance of eradicating corruption, they have not been motivated to develop anti-corruption behavior. Another thing that needs to be considered is reviewing the learning media and the learning process. It is also necessary for further exploration regarding the value of independence, discipline, hard work, and courage on the $\mathrm{Y} 1$ variable where students still have a lot to practice. Meanwhile, on Variable Y2, bribery and nepotism should be concerned. Students 
understand that this can be an entry point for corruption, but they still have not explicitly stated that they will not engage in bribery and nepotism. The anti-corruption learning model that is integrated in the curriculum (Hakim, 2012), (Gusnardi, 2014) can be an alternative to instill these anti-corruption values.

The learning process that has been conducted gave an insignificant impact on the anti-corruptive behavior of the respondents. This definitely should be given more attention in order to gain long-term impact, for example, when students are involved in various community problems. Student contributions can be in the form of actions against corruption, such as the anticorruption social movement of $1,000,000$ facebookers that support Chandra Hamzah and Bibit Samad Riyanto (Sulistyo, Ponco Budi and Azmawati, 2016); (Yulianita et al., 2020). Students can also declare a petition to eradicate corruption. This action is one of the social capitals (Sulistiawati, 2012), which can predict the risk of corruption in a city (Wachs et al., 2019).

As agents of change, students should be aware of the importance of preventing corruption and developing anti-corruption behavior so that the youth character of anti-corruption can be formed. Students can experience the learning process by gaining knowledge, attitude, values, and skills that provide a robust base to learn more or survive (Duryat \& Sahrodi, 2021). Normatively and sociologically, the essence of anti-corruption values socialization in university is preventive action to corruption committed by the community (Rakhmat, 2015).

Besides setting the anti-corruption course as mandatory, strategies in incorporating anti-corruption and awareness through hidden curriculum and morality education are also important. Some practices such as good behaviour, discipline, and good relationship among students-teachers are fostered in the daily activities at school. It is of necessity to increase such awareness among students so that they can avoid any action related to corruption (Salistina, 2015).

The anti-corruption values integration process can be executed by the lecturer providing examples, such as: value of transparency, punctuality, democratic learning process, budget allocation transparency for students' activity, discipline, and honesty. On the other hand, the process of strengthening anti-corruption values can be executed both verbally and non-verbally, such as: reprimanding, reminding, imposing the sanction, and academic credit bonus during the course (Sukmana et al., 2020). By implementing those efforts, the majority of students are expected to possess positive attitude to anti-corruption behavior. The results prove the importance of internalizing integrity learning through the socialization process on cognitive, affective, and psychomotor skills of the students. Cognitive skill means students are able to apply concepts, connect several syntheses, and problem solving during discussion. Affective skill means strengthening attitude, interest, emotions, and even changing the attitude. Furthermore, lecturers should provide the negative impact of corruption and support students to possess integrity to develop the anti-corruption emotional and attitude. The increase of cognitive skill is usually followed by the increase of affective and psychomotor skill. The students are not hesitant to remind, inform, and prevent others who commit to corruptive behaviour. "Eradicate corruption" in educational context means to perform a series of efforts to create a generation of "good people".

\section{Conclusion}

From this research, we can conclude that all of the respondents categorized as having high anti-corruption values behavior. Unfortunately, the correlation between their understanding and anti-corruption values is moderate. Whereas, the correlation between their understanding and corruptive behavior is low. The result of the regression test showed that the impact of Variable $X$ on both $Y 1$ and $Y 2$ is relatively insignificant.

The impact of the understanding of anti-corruption values on anti-corruption behavior is categorized as weak. There are other aspects that should be examined. The understanding of anti-corruption values and the commitment to not act corruptively could be gained not only through the courses at university, but also in the family. However, anti-corruption values should be strengthened, thus the students are able to uphold the anti-corruption values and corruptive behavior in the academic scope could be prevented. 


\section{Acknowledgment}

This study is a collaborative study between Mercu Buana University and Paramadina University. Thus, we would like to thank the Director of Mercu Buana University, especially the Dean of the Faculty of Communication, Ponco Budi Sulistyo, Ph.D., the Director of Research and Technology, Publication, and Domestic Affair, Dr. Devi Fitrianah S.Kom., MTI,. We would also like to thank the Director of Paramadina University, especially the Dean of the Faculty of Philosophy and Cultural Sciences, Tia Rahmania, M.Psi, Psikolog, and the Director of Institute for Research and Community Service, Dr. Sunaryo.

\section{References}

Attanasi, G., Rimbaud, C., \& Villeval, M. C. (2019). Embezzlement and Guilt Aversion. Journal of Economic Behavior \& Organization, 167, 409-429.

Denisova-Schmidt, E., Prytula, Y., \& Rumyantseva, N. L. (2019). Beg, borrow, or steal: determinants of student academic misconduct in Ukrainian higher education. Policy Reviews in Higher Education. https://doi.org/10.1080/233 22969.2018.1518726

Dimyati, T. R. (2018). PEMBENTUKAN KARAKTER MAHASISWA DALAM SISTEM PENDIDIKAN TINGGI ISLAM. TADRIS: Jurnal Pendidikan Islam. https://doi. org/10.19105/tjpi.v13i1.1716

Duryat, H. M., \& Sahrodi, H. J. (2021). Manajemen Pendidikan AntiKorupsi:(Wacana Kritis atas Etika Kekuasaan dan Budaya Mematuhi Melalui Pendidikan). K-Media.

Effendy, O. U. (2003). IImu, Teori dan Filsafat Komunikasi. In Citra Aditya.

Gusnardi. (2014). Pendidikan Anti Korupsi di Perguruan Tinggi: Perlukah? Pekbis.

Habibi, A. (2018). Doktrinisasi Anti Korupsi (Program Perguruan Tinggi Menanamkan Semangat Anti Korupsi Ke Alam Bawah Sadar Mahasiswa). SALAM: Jurnal Sosial Dan Budaya Syar-I. https://doi. org/10.15408/sjsbs.v5i1.7903

Hakim, L. (2012). Model Integrasi Pendidikan Anti Korupsi dalam Kurikulum Pendidikan Islam. Taklim.

Handayani, D. M. (2019). KORUPSI. Pengarah: Jurnal Teologi Kristen. https:// doi.org/10.36270/pengarah.v1i1.3

Handoyo, E. (2013). Pendidikan Antikorupsi. Ombak Dua. http://lp3.unnes.ac.id/ v2/wp-content/uploads/2019/08/

Pendidikan-Anti-Korupsi-SuplemenMKU-Pend.-Konservasi.pdf

Harahap, A. J. (2018). Risywah dalam Perspektif Hadis. Diroyah: Jurnal Studi IImu Hadis, 2(2), 109-120.

Hermawan, H. (2018). Kebijakan-Kebijakan Pendidikan Agama Islam Dalam Memberantas Korupsi. Tarbiyatuna. https://doi.org/10.31603/tarbiyatuna. v9i1.2062

Illahi, B. K. (2019). Internalisasi Nilai Antikorupsi Melalui Pencegahan dan Pengendalian Benturan Kepentingan di Perguruan Tinggi. Supremasi Hukum: Jurnal Penelitian Hukum. https://doi. org/10.33369/jsh.28.2.136-152

Iqbal, Q., \& Ahmad, N. H. (2020). Workplace Spirituality and Nepotism-favouritism in Selected ASEAN Countries: The Role of Gender as Moderator. Journal of Asia Business Studies, 14(1), 31-49. https:// doi.org/10.1108/JABS-01-2018-0019

Khamdan, M. (2014). Jihad Akademik Kalangan Perguruan Tinggi Islam Melawan Korupsi (Pemaknaan Akademisi atas Kerancuan Fiqih dan Budaya Terhadap Korupsi). Jurnal Penelitian.

Komalasari, K., \& Saripudin, D. (2015). Integration of anti-corruption education in school's activities. American Journal of Applied Sciences, 12(6), 445.

Lestari, P., \& Romdiani, N. S. (2018). Efektifitas Pembelajaran Dengan Media Kartu Untuk Meningkatkan Kemampuan Pemahaman Matematis Siswa. Jurnal Gantang. https://doi.org/10.31629/ jg.v3i1.304

Lina Miftahul Jannah \& Bambang Prasetyo. (2003). Pendekatan Kuantitatif. Materi Pokok Metode Penelitian Kuantitatif.

Madrim, S. (2021). Sama, Skor Indeks Persepsi Korupsi Indonesia dan Gambia. VOA Indonesia. https:// www.voaindonesia.com/a/sama-skorindeks-persepsi-korupsi-indonesia-dangambia/5756699.html

Mohd Khairuddin Abdullah, Khalid $\mathrm{Hj}$ Johari, Ag Yusof Ag Chuchu, \& Halimah Laji. (2014). Komunikasi guru dalam bilik darjah dan tingkah laku delinkuen murid sekolah menengah. Jurnal Pemikir Pendidikan.

Nugraheni; Lestari, T. W. S. (2017). Mahasiswa Pelopor Gerakan Antikorupsi (pertama). Deepublish. https://www. google.co.id/books/edition/Mahasiswa_ Pelopor_Gerakan_Antikorupsi/WMo9Dw AAQBAJ?hl $=$ en $\& \mathrm{gbpv}=1 \& \mathrm{dq}=$ PENDIDIK 
AN+ANTIKORUPSI+book\&printsec $=$ fron tcover

Nurul Salmi Mohd Dazali, \& Mohd Isha Awang. (2014). Communication Skill Among Undergraduate Students of Education in Northern Malaysia. Malay Language Education Journal - MyLEJ. https://doi. org/10.1017/CBO9781107415324.004

Oktarina, Y., \& Abdullah, Y. (2017). Komunikasi dalam Perspektif Teori dan Praktik. Deepublish.

Pramelani. (2018). Efek Kognitif, Afektif dan Behavioral pada Kampanye Registrasi Prabayar Seluler. Jurnal Komunikasi.

Purba, N., \& Zaini, S. (2018). Sosialisasi Pembudayaan Pendidikan Anti Korupsi Berbasis Madrasah untuk Menanamkan Anti Korupsi bagi Siswa. AMALIAH: JURNAL PENGABDIAN KEPADA MASYARAKAT. https://doi.org/10.32696/ ajpkm.v2i1.104

Puspito, N., \& Elwina, M. (2016). Buku Panduan Dosen Pembelajaran Pendidikan Anti Korupsi Untuk Perguruan Tinggi. Biro Kerja Sama dan Komunikasi Publik, Kementerian Riset, Teknologi, dan Pendidikan Tinggi. http:// Ildikti12.ristekdikti.go.id/wp-content/ uploads/2019/09/01-Buku-PanduanDosen-PAK-untuk-Perguruan-Tinggi.pdf

Rakhmat, M. (2015). Kewenangan Kejaksaan dalam Pengembalian Aset Hasil Korupsi melalui Instrumen Hukum Perdata. Mimbar: Jurnal Sosial Dan Pembangunan, 31(1), 201-210.

Saifulloh, P. P. (2017). Peran Perguruan Tinggi dalam Menumbuhkan Budaya Anti Korupsi di Indonesia. Jurnal Hukum \& Pembangunan. https://doi. org/10.21143/.vol47.no4.1591

Salama, N. (2014). Motif dan Proses Psikologis Korupsi. Jurnal Psikologi. https://doi.org/10.22146/jpsi.6946

Salistina, D. (2015). Pendidikan Anti Korupsi melalui Hidden Curriculum dan Pendidikan Moral. Ta'allum: Jurnal Pendidikan Pendidikan Islam, 3(2), 163-184. https://doi.org/10.21274/ taalum.2015.3.2.163-184

Soemanto, R., Sudarto, \& Sudarsana. (2014). Pemahaman Masyarakat tentang Korupsi. Yustisia Jurnal Hukum, 3(1), 8288. https://doi.org/10.20961/yustisia. v3i1.10124

SOFWAN, M., SETIONO, P., ELSAYED, A. E. M., \& SAUDAGAR, F. (2018). Fighting against Corruption through Character Education: The Voices of Indonesian Primary School Teachers. | IRJE| Indonesian Research
Journal in Education|, 86-96.

Sugiyono. (2016). Metode Penelitian Kuantitatif, Kualitatif, dan R\&D. In Alfabeta, CV.

Sukmana, O., Agustino, H., \& Widodo, E. R. P. (2020). Implementation of Modeling and Reinforcement Process from Lecturers in Forming Anti-Corruption Attitude of Student Activist: A Study at University of Muhammadiyah Malang, Indonesia. International Journal of Psychosocial Rehabilitation, 24(8), 1341-1350.

Sulistiawati, L. Y. (2012). 'Social Capital' and Corruption Demolition in Indonesia Case Studies: Indonesia's Forest Fires and Prita Mulyasari. SSRN Electronic Journal. https://doi.org/10.2139/ssrn.2158818

Sulistyo, Ponco Budi and Azmawati, A. A. (2016). The Roles Of Facebook In Creating New Anti- Corruption Social Movement Through Online Community In Indonesia. International Journal of Scientific and Research Publications, Volume 6(Issue 7, July 201633 ISSN 2250-3153), 33-37. http://www.ijsrp. org/research-paper-0716/ijsrp-p5506. pdf

Suryani, I. (2015). Penanaman Nilai-Nilai Anti Korupsi di Lembaga Pendidikan Perguruan Tinggi sebagai Upaya Preventif Pencegahan Korupsi. Jurnal Visi Komunikasi.

Wachs, J., Yasseri, T., Lengyel, B., \& Kertész, J. (2019). Social capital predicts corruption risk in towns. Royal Society Open Science. https://doi.org/10.1098/ rsos. 182103

Widhiyaastuti, I., \& Ariawan, I. G. K. (2018). Meningkatkan Kesadaran Generasi Muda untuk Berperilaku Anti Koruptif melalui Pendidikan Anti Korupsi. Acta Comitas, 3(1), 17-25.

Williams, C. C., Martinez-Perez, A., \& Kedir, A. (2016). Does Bribery have a Negative Impact on Firm Performance? A Firmlevel Analysis Across 132 Developing Countries. International Journal of Entrepreneurial Behavior \& Research.

Wisman, Y. (2017). Komunikasi Efektif dalam Dunia Pendidikan. Jurnal Nomosleca. https://doi.org/10.26905/nomosleca. v3i2.2039

Wiyono, S. (2015). Tantangan Pendidikan Anti Korupsi: Gratifikasi, Suap dan Pemerasan Membayangi Pejabat dan Aparat Penegak Hukum. Revolusi Pendidikan Karakter Bangsa.

Yulianita, N., Nurrahmawati, N., \& Maryani, A. (2020). Analysis of the Anti-Corruption 
SARAGIH. et.al. The Impact of Students' Understanding of Anti-Corruption Values on Anti-Corruption Behavior

Campaign for Engagement and Action on Social Media. MIMBAR: Jurnal Sosial Dan Pembangunan, 36(1), 110-118.

Yusup, F. (2018). Uji Validitas dan Reliabilitas Instrumen Penelitian Kuantitatif. Jurnal Tarbiyah: Jurnal Ilmiah Kependidikan. https://doi.org/10.18592/tarbiyah. v7i1.2100 